\title{
Effect of household pet ownership on infant immune response and subsequent sensitization
}

\author{
This article was published in the following Dove Press journal: \\ Journal of Asthma and Allergy \\ 27 August 2010 \\ Number of times this article has been viewed
}

\author{
Angela Simpson \\ Manchester Academic Health Science \\ Centre, NIHR Translational Research \\ Facility in Respiratory Medicine, \\ University Hospital of South \\ Manchester NHS Foundation Trust, \\ Manchester, UK
}

\begin{abstract}
Sensitization to pets is a major risk factor for asthma. There are many reports on the relationship between household pets, sensitization to the pet, and sensitization to other allergens, often with conflicting results. Pet ownership is not random, and household pets are associated with exposures other than pet allergens. We will review some of the evidence regarding the effects of household pets on infant immune responses, focusing on data from birth cohort studies. It remains unclear precisely why some children develop specific sensitizations to pets whilst others do not in the face of equivalent exposures, but it is likely to be due to gene-environment interactions. Further long-term follow-up of children in whom neonatal and infant immune responses have been measured is necessary to understand how these events occur and how they relate to subsequent disease.
\end{abstract}

Keywords: pets, sensitization, immune response

\section{Introduction}

The development of allergic responses to inhaled allergens is the single biggest risk factor for asthma in the developed world. ${ }^{1}$ Therefore, mechanisms and exposures associated with the development of allergic sensitization are the subject of much study. Although it is generally accepted that some exposure to the relevant allergen is necessary for the development of sensitization, the dose and timing of the necessary exposure remains unclear. It is likely that exposure to environmental factors other than the allergen, such as microbials, are important. Allergic sensitization is familial, suggesting a genetic component.

There are many reports of the relationship between household pets, sensitization to the pet, and sensitization to other allergens, often with conflicting results. ${ }^{2}$ Individuals may become sensitized to pets even though they have never lived with pets and have very low levels of pet allergens in the home. ${ }^{3}$ Pets are a major source of allergen; levels of allergen in the homes of pet owners are approximately 250 -fold higher than levels seen in homes of nonpet owners. ${ }^{4,5}$ But pets are the source of exposures other than their allergens; some reports suggest homes with pets contain higher levels of endotoxin, ${ }^{6,7}$ and that homes with dogs have the highest airborne levels of endotoxin, ${ }^{8}$ but this difference in levels has not been confirmed by other studies. ${ }^{9}$ Pet owners also exhibit differing social characteristics, including lower educational level, ${ }^{10}$ and increased cigarette smoking amongst parents, ${ }^{11}$ with the children less likely to be breastfed or attend day care. ${ }^{11}$

The keeping of pets in the home is generally an intentional choice, governed by many factors, such as presence of symptoms on exposure, familial habits ("we always 
have dogs/cats"), and restrictions imposed by the type of accommodation. ${ }^{10}$ Levels of allergen in the home reflect habits of pet ownership; in Africa where cats are kept outdoors to control rodents, indoor levels of allergen are much lower than those seen in Western city homes where cats are frequently kept indoors. ${ }^{12}$

Sensitization to pets is a major risk factor for asthma in areas of the world with a high proportion of pet ownership, ${ }^{13}$ and even in some ${ }^{14}$ but not all ${ }^{15}$ areas with a low proportion of pet ownership. Patients with established asthma who are sensitized to pets and exposed either to pets or to high levels of pet allergen tend to have more severe asthma than those who are not exposed. ${ }^{16}$ Cat and dog allergens are ubiquitous in areas with a high proportion of pet ownership. ${ }^{4,17}$ It is also interesting to note that across Europe, the community prevalence of sensitization to cats amongst noncat owners correlates positively with community cat ownership rates, ie, more cats in the community means more noncat owners will be sensitized. ${ }^{18}$ It is likely that pet allergen is carried into public places on the clothes of pet owners. ${ }^{19}$ Allergencarrying particles are small, can remain airborne for long periods, and are detectable even in homes that have never contained a pet. ${ }^{5}$

Immune responses in infancy can be measured by performing skin prick tests to a panel of allergens in children, by measuring immunoglobulin E (IgE) and $\operatorname{IgG}$ antibodies in peripheral or cord blood, and also by measuring responses of peripheral or cord blood mononuclear cells to mitogens or allergens. The mechanisms involved in the development of immune responses are beyond the scope of this review, but are elegantly described elsewhere. ${ }^{20}$ In the rest of the review, some of the evidence regarding the effects of household pets on infant immune responses is considered, focusing on data from birth cohort studies.

\section{Neonatal and infant immune responses}

Immune responses in infancy have been the subject of much study. Theoretically, if one could identify children at high risk of allergy at or soon after birth, suitable interventions could be implemented to reduce the risk of disease. This aspiration has incentivized researchers to make use of the large quantities of blood from the umbilical cord to quantify innate immune responses in relation to allergy. Much smaller quantities of blood are available from infants, making these studies more challenging and more limited in the number of measurements that can be made. Early infancy is a period of rapid maturation of the immune system, ${ }^{21}$ from the relative Th2 skewing within an overall attenuated immune system to the development of immune competence required to survive extrauterine life. ${ }^{22}$ Therefore, infancy is a critical time during which to observe the development of the maturing immune system in terms of both general and allergen-specific responses in relation to external factors, in particular microbial exposure.

\section{Cord blood antibody responses}

Work started with the measurement of IgE in cold blood serum back in the early $1970 \mathrm{~s} .{ }^{23}$ Although early studies suggested that measurement of cord IgE was useful for predicting development of allergic disease with high specificity, the sensitivity of this test was low, ie, low cord blood IgE does not exclude the possibility of developing allergic disease. ${ }^{24,25}$ Later studies suggested the measurement of cord blood IgE was no better at predicting the development of allergic disease in early childhood than family history. ${ }^{26,27}$ More recent studies have suggested that raised cord blood IgE, although not a good predictor of early disease, may predict allergic disease in later childhood. ${ }^{28}$

Allergen-specific IgE is generally not detectable in cord blood, ${ }^{29}$ but IgG to specific allergens can be quantified and has been shown to correlate closely with maternal levels, suggesting passive transfer. ${ }^{29}$ However, one large birth cohort study from the US has suggested that the presence of pets in the home during pregnancy (either cats or dogs) is associated with a lower mean cord IgE level at birth. ${ }^{30}$

Therefore, there is limited evidence to suggest that pet ownership during pregnancy may influence cord blood serology, but not in an allergen-specific sense.

\section{Cord blood and peripheral mononuclear cell responses}

The isolation and culture of mononuclear cells from cord blood (CBMCs) has allowed investigators to measure the responsiveness of these cells to polyclonal stimulants, such as the phytohemagglutinin (PHA) antigen or to specific allergens (such as house dust mite extract, cat extract, or Der p1 or Fel d1) both in terms of proliferative responses of the cells and cytokine production. In a study in which both cord blood $\mathrm{IgE}$ and $\mathrm{CBMC}$ responses (to food allergens) were measured, proliferation responses of CBMCs were better predictors of subsequent allergic disease than cord IgE or family history, with the best sensitivity from combining raised cord IgE and proliferative response. ${ }^{31}$

Nonspecific proliferative responses tend to be lower amongst infants at higher risk of disease, suggesting that 
a higher genetic risk of atopy is associated with delayed postnatal maturation of T-cell competence. ${ }^{32}$ Furthermore, it is now widely acknowledged that allergen-specific responses develop postnatally. Although some early studies suggested in utero priming of cord blood T-cells, ${ }^{33}$ it is now recognized that these apparently allergen-specific responses were due to activity of recent thymic emigrant $\mathrm{CD}^{+} \mathrm{T}$-cells. These cells express altered antigen receptors (lacking the fine specificity of conventional T-cell receptors), are able to interact with low affinity in a wide range of allergens on first contact, and proliferate in the presence of interleukin-2 (IL-2). ${ }^{34}$

Although many studies have measured both cord and peripheral blood mononuclear cell (PBMC) responses in early life, few have analyzed the results in the context of pet ownership or investigated pet allergen-specific responses, and no study has done both.

\section{Effect of pets on nonspecific immune responses}

In a small study designed to compare cytokine responses at birth and at age three months in children born on a farm and those not born on a farm, Roponen et al measured interferon-gamma (IFN- $\gamma$ ) responses of CBMCs and PBMCs to a mitogen (combined PMA and Con A). ${ }^{35}$ There were no differences in IFN- $\gamma$ production at birth, but by the age of three months, children exposed to cats or dogs at home showed an enhanced IFN- $\gamma$ response. A similar effect was seen for children on farms, and the IFN- $\gamma$ response correlated with domestic endotoxin exposure (but not ergosterol, muramic acid, or peptidoglycan). ${ }^{36}$ Because more pets were kept by farmers and the study was too small to conduct a multivariate analysis, it was not possible to determine whether domestic pets or the farming environment was the predictor of the enhanced response. However, the effects could not be explained by maternal atopy. Because the children were only followed to the age of three months, it was not possible to relate $\mathrm{PBMC}$ responses to any meaningful clinical outcomes. The authors acknowledge the small scale of this cohort, and a larger cohort has been recruited by this group, although $\mathrm{CBMC}$ responses to mitogens have not been published yet in the context of pet ownership. ${ }^{37}$

Within the Childhood Origins of Asthma birth cohort population, investigators have tried to relate neonatal and early-life immune responses to clinical symptoms in early life. They have shown a reduced prevalence of allergic sensitization and eczema at the age of 1 year amongst those with a dog, ${ }^{38}$ and that by the age of 3 years, the presence of a dog at birth was no longer protective for allergic sensitization, but there was reduced wheeze in this group. ${ }^{39}$ Immune responses were analyzed in the context of pet ownership by comparing the PHA-stimulated PBMC cytokine response profiles at the age of 1 and 3 years, between those with and without dogs at birth. ${ }^{38,39}$ At both time points, those with a dog at birth showed increased IL-10 and IL-13 production in response to the mitogens, compared with those without a dog. A dose-related association could also be demonstrated for Can f1 levels. There was no apparent difference in IFN- $\gamma$ and IL-5 responses, and no association was seen with endotoxin levels in the home. The immune effects demonstrated were, like the clinical effects, restricted to dog owners; no effects were seen for cat owners and the authors concluded that dog exposure does contribute to the development of the immune system. Long-term follow-up of this cohort is needed to see how these observations relate to important clinical outcomes in later life.

\section{Effect of pets on allergen-specific responses}

Within the setting of the Epidemiology of Homes Allergens and Asthma Study, investigators measured responses of PBMCs in children aged 2-5 years to cat allergen Fel d1, with results available in 151 children, only 31 of whom had evidence of an $\mathrm{IgE}$ response (detectable specific $\operatorname{IgE}$ or raised total $\mathrm{IgE}) .{ }^{40} \mathrm{Fel}$ d1-specific IL-13 responses were significantly higher amongst children showing an $\operatorname{IgE}$ response, demonstrating that $\mathrm{T}$-cell priming to specific allergens can occur by the age of 2 years.

In summary, studies of cord blood suggest that although pet exposure during pregnancy has been associated with reduced cord blood IgE, there is no evidence that pet exposure is associated with altered T-cell responses at birth. However, postnatal exposure to pets has been associated both with reduced IFN- $\gamma$ (cats or dogs) production and increased IL-10 and IL-13 (dogs only).

\section{Pets and development of IgE responses}

The population-based birth cohort is the ideal model in which to study pet exposure, early immune responses, and subsequent sensitization. Further information can also be gained from high-risk birth cohorts. The results of many such studies are summarized in Table 1 . The prevalence of sensitization is very low in the first few years of life and increases markedly during childhood. ${ }^{41}$ Therefore, although 
Table I Summary results from birth cohort studies

\begin{tabular}{|c|c|c|c|c|c|}
\hline Study & $\begin{array}{l}\text { Design, age, } \\
\text { numbers }\end{array}$ & $\begin{array}{l}\text { Cat/dog } \\
\text { ownership }\end{array}$ & $\begin{array}{l}\text { Definition } \\
\text { of exposure }\end{array}$ & $\begin{array}{l}\text { Outcome } \\
\text { measures }\end{array}$ & $\begin{array}{l}\text { Association between } \\
\text { cat/dog exposure and AS }\end{array}$ \\
\hline Hagendorens et $\mathrm{a}^{51}$ & $\begin{array}{l}\text { UBC } \\
\text { I year } \\
n=810\end{array}$ & $\begin{array}{l}\text { C: } 53 \% \\
\text { D: } 35 \%\end{array}$ & $\begin{array}{l}\text { C, D } \\
\text { During } \\
\text { first year of life }\end{array}$ & $\begin{array}{l}\mathrm{Q} \\
\lg \mathrm{E}\end{array}$ & $\begin{array}{l}\text { Sens to C: NR } \\
\text { Sens to D: NR } \\
\text { AS: NA }\end{array}$ \\
\hline Custovic et $\mathrm{al}^{46}$ & $\begin{array}{l}\text { UBC } \\
\text { I year } \\
n=517\end{array}$ & $\begin{array}{l}\text { C: } 15 \% \\
\text { D: } 14 \%\end{array}$ & C, D ownership & Q spt, IgE & $\begin{array}{l}\text { Sens to } C \text { : increased with } C \text { if } \\
\text { positive } F H \\
\text { Sens to D: NA } \\
\text { AS: NR }\end{array}$ \\
\hline Arshad et al $\mathrm{al}^{42,43}$ & $\begin{array}{l}\text { UBC } \\
4 \text { years } \\
n=1218\end{array}$ & $\begin{array}{l}\text { C: } 39 \% \\
\text { D: } 30 \%\end{array}$ & $\begin{array}{l}\text { C, D } \\
\text { current }\end{array}$ & Spt, Q & $\begin{array}{l}\text { Sens to C: NA } \\
\text { Sens to D: NA } \\
\text { AS: NR }\end{array}$ \\
\hline Torrent et $\mathrm{a}^{47}$ & $\begin{array}{l}\text { UBC } \\
4 \text { years } \\
n=1019\end{array}$ & $\begin{array}{l}\text { C: } 16.7 \% \text { in } \\
\text { first year } \\
\text { D: NR }\end{array}$ & $\begin{array}{l}\text { Fel dl, Can } \\
\mathrm{fl} \text { at } 3 \text { months }\end{array}$ & $\begin{array}{l}\lg E \\
Q\end{array}$ & $\begin{array}{l}\text { Sens to C: increased with } \\
\text { increasing Fel } d I \text { exposure } \\
\text { Sens to D: NR } \\
\text { AS: NR }\end{array}$ \\
\hline Perzanowski et $\mathrm{a}^{41}$ & $\begin{array}{l}\text { UBC } \\
\text { Age } 2(n=323) \\
3(n=336) \text { and } \\
5(n=242)\end{array}$ & $\begin{array}{l}\text { C: } 10 \%-25 \% \\
\text { D: NR }\end{array}$ & Fel dI, C & $\lg E, \lg G$ & $\begin{array}{l}\text { Sens to } C \text { : increased in } C \text { owners } \\
\text { by age } 2 \text {, NA by age } 5 \text { years } \\
\text { Sens to } D: \\
\text { AS: NR }\end{array}$ \\
\hline Ownby et $\mathrm{al}^{43}$ & $\begin{array}{l}\text { UBC } \\
6-7 \text { yrs } n=474\end{array}$ & $\begin{array}{l}\text { C: } 32 \% \text { in infancy } \\
\text { D: } 45 \% \text { in } \\
\text { infancy }\end{array}$ & $\begin{array}{l}\text { C, D, current } \\
\text { infancy, Fel dI }\end{array}$ & Spt, lgE, BHR & $\begin{array}{l}\text { Sens to C: NA } \\
\text { Sens to D: decreased with D in } \\
\text { infancy } \\
\text { AS: decreased with } 2 \text { or more } \\
\text { D or C }\end{array}$ \\
\hline Remes et al ${ }^{44}$ & $\begin{array}{l}\text { UBC } \\
\text { I3 years } n=1076 \\
(n=613 \text { with } \lg E)\end{array}$ & $\begin{array}{l}\text { C: } 22 \% \\
\text { D: } 30 \%\end{array}$ & $\begin{array}{l}C, D \text { indoors } \\
\text { infancy }\end{array}$ & $\begin{array}{l}\text { Spt (but not } \\
\text { to } D \text { ), Q }\end{array}$ & $\begin{array}{l}\text { Sens to } C: N A \text { at } I I \text { years } \\
\text { Sens to D: NR } \\
\text { AS: NA }\end{array}$ \\
\hline Gern et $\mathrm{al}^{38}$ & $\begin{array}{l}\text { HRBC } \\
\text { I year } \\
n=285\end{array}$ & $\begin{array}{l}\text { C: } 29 \% \\
\text { D: } 35 \%\end{array}$ & C, D ownership & $\mathrm{Q}, \lg \mathrm{E}$ & $\begin{array}{l}\text { Sens to C: NR at I year, NA at } \\
3 \text { years } \\
\text { Sens to D: NR at I year, NA at } \\
3 \text { years } \\
\text { AS: Reduced with D at I year, } \\
\text { NA at } 3 \text { years; NA for C at I or } \\
3 \text { years }\end{array}$ \\
\hline Brussee et $\mathrm{a}^{45}$ & $\begin{array}{l}\text { SBC } \\
4 \text { years, } 8 \text { years } \\
\text { (high- and low-risk } \\
\text { only) } \\
\mathrm{n}=1248 \text { with } \\
\text { lgE at } 8 \text { years }\end{array}$ & $\begin{array}{l}\text { C: } 34 \% \\
\text { D: } 16 \%\end{array}$ & $\begin{array}{l}\text { Fel } \mathrm{dl} \text {, Can } \mathrm{fl} \\
\text { at } 3 \text { months }\end{array}$ & $\begin{array}{l}\lg E \\
Q\end{array}$ & $\begin{array}{l}\text { Sens to C: increased with } \\
\text { increasing Fel } \mathrm{dl} \text { exposure if } \\
\text { mother nonatopic at } 4 \text { years; NA } \\
\text { at } 8 \text { years, } \\
\text { Sens to D: NA at } 4 \text { years or } \\
8 \text { years } \\
\text { AS: NR at } 4 \text { years; reduced with } \\
\text { dog at } 8 \text { years }\end{array}$ \\
\hline Munir et $\mathrm{al}^{3}$ & $\begin{array}{l}\text { HRBC } 5 \text { years } \\
\mathrm{n}=86\end{array}$ & $\begin{array}{l}\text { C: } 8 \% \\
\text { D: } 9 \%\end{array}$ & $\begin{array}{l}\text { C, D, current, } \\
\text { peak Fel dl, } \\
\text { Can } \mathrm{fl}\end{array}$ & Spt & $\begin{array}{l}\text { Sens to C: NA with Fel dI levels } \\
\text { or C ownership } \\
\text { Sens to D: Too few sens to D to } \\
\text { comment } \\
\text { AS: NR }\end{array}$ \\
\hline Burr et $\mathrm{al}^{50}$ & $\begin{array}{l}\text { HRBC } \\
7 \text { years } \\
n=440\end{array}$ & $\begin{array}{l}\text { C: NR } \\
D: N R\end{array}$ & C, D current & Spt, IgE, Q & $\begin{array}{l}\text { Sens to C: NR } \\
\text { Sens to D: NR } \\
\text { AS: Reduced lgE in C or D in } \\
\text { infancy. NA for spt }\end{array}$ \\
\hline $\mathrm{Lau}^{9,48}$ & $\begin{array}{l}\mathrm{SBC} \\
7 \text { years } \\
n=939\end{array}$ & $\begin{array}{l}\text { C: NR } \\
\text { D: NR } \\
\text { Levels of Fel } \\
\text { dI generally low }\end{array}$ & $\begin{array}{l}\text { C current } \\
\text { Fel dl }\end{array}$ & $\begin{array}{l}\lg E \text { and } \lg G \\
\text { to cat, } Q\end{array}$ & $\begin{array}{l}\text { Sens to C: increased with higher } \\
\text { Fel dI levels at } 3 \text { and } 7 \text { years; by } \\
\text { age } 10 \text { years NA } \\
\text { Sens to D: NR } \\
\text { AS: NR }\end{array}$ \\
\hline
\end{tabular}

Abbreviations: C, cat; D, dog, BC, birth cohort; S, selected; U, unselected; HR, high risk; Q, questionnaire; NR, not reported; NA, no association; FH, family history; spt, skin prick test; IgE, specific IgE; AS, allergic sensitization ( $\geq$ I allergens); UBC, unselected birth cohort. 
infant responses may give some insight into how these develop, the patterns do change with time.

\section{Sensitization to cats}

Examining first the effects of cat ownership on specific sensitization to cats, the results appear initially inconsistent, with some studies reporting no association ${ }^{39,42-44}$ and others reporting an increase in risk. ${ }^{3,45-47}$ However, if one takes the example of the MAS-90 cohort, ${ }^{9,48}$ where results of exposure (domestic Fel d1) are reported across time, although higher Fel d1 exposure was associated with an increased likelihood of IgE to cats at the age of 5-7 years, this effect was no longer seen by the age of 10 years. Similarly, amongst a cohort of inner city children from New York, significantly more children with a cat at home were sensitized to cats at the age of 2 years $(9.8 \%$ of cat owners versus $1.5 \%$ of noncat owners), but by the age of 5 years, those without a cat were sensitized at a similar prevalence $(20.3 \%$ of cat owners versus $12.4 \%$ of noncat owners). ${ }^{41}$ Also, amongst children from the Tucson Children's Respiratory Study, ${ }^{44}$ where cat sensitization in relation to cat ownership is reported only at the age of 11 years, there was no association.

We speculate that, amongst cat owners, sensitization occurs earlier in life, particularly for high-risk children. As children age and experience further exposure to cat allergen in the community, those without cats at home, but with the genetic predisposition, become sensitized, so that by mid childhood (approximately 10 years of age) there is no difference in the prevalence of cat sensitization between those with and without cats in the home.

Given the suggested role of IgG and IgG4 antibodies to cat allergen in a form of tolerance (the modified Th2 response) ${ }^{49}$ some investigators have included these measures in serologic testing. In MAS-90, IgG responses to cat allergen were also measured and were found to correlate with domestic exposure to Fel d1. ${ }^{9}$ Amongst those with detectable IgG to cats, approximately $50 \%$ had evidence of $\mathrm{IgE}$ responses. Although children with IgG but not IgE were at low risk of wheeze, those with an IgE response and IgG to Fel d1 were at the highest risk of wheeze. It was clear that amongst those with high IgE to cats, the presence of IgG to cats was not protective, but it remained unclear as to why some children developed IgG with IgE and some without IgE (this could not be easily related to exposure).

IgG antibodies to Fel d1 were also measured in the Epidemiology of Home Allergens and Asthma Study, and were found to correlate with domestic Fel d1 exposure by the age of 2 years and, in the majority, were found to occur without any evidence of IgE to cats. ${ }^{41}$ The presence of these antibodies was associated with eczema (but not wheeze) at an early age, but the long-term significance of this is unclear.

\section{Sensitization to dogs}

Fewer studies have been reported for dog ownership and sensitization to dogs, but most birth cohort studies report no association at any time point. $3,39,42,45,46$ One notable exception is the Children's Allergy Study which found a reduced risk of sensitization to dogs amongst those with dogs in the home, with the strongest effect seen for those with two or more dogs. ${ }^{43}$

\section{Pet ownership and general allergic sensitization}

There have been no studies suggesting that pet ownership confers an increase in the risk for allergic sensitization, and several studies have suggested pet ownership is associated with less allergic sensitization ${ }^{39,43,50}$ with others showing no association. ${ }^{44,51}$ The long-term follow-up of these and larger populations, together with measures of environmental exposures, is required to delineate the complex interaction of exposure and serologic responses, within the context of genetic predisposition.

\section{Conclusion}

Pet allergens are ubiquitous in areas where pet ownership is common. The data from birth cohort studies suggest that for sensitization to cats, those with cats in the home are at increased risk of sensitization during the preschool years, but during the school years those without a cat at home may become sensitized and, by approximately 10 years of age, there is no difference in specific sensitization between the groups. There is no apparent association between dog ownership and specific sensitization to dogs, although dog owners are apparently at a reduced risk for allergic sensitization in general.

It remains unclear why some children do and others do not develop specific sensitizations in the face of equivalent exposures; this likely represents a gene-environment interaction, as recently demonstrated by our group for cat ownership, for Filaggrin and eczema. ${ }^{52}$

Long-term follow-up of children in whom neonatal and infant T-cell responses have been measured is necessary to understand how these early findings relate to later disease. 


\section{Disclosure}

The author reports no conflict of interest in this work.

\section{References}

1. Weinmayr G, Weiland SK, Bjorksten B, M, et al. Atopic sensitization and the international variation of asthma symptom prevalence in children. Am J Respir Crit Care Med. 2007;176:565-574.

2. Simpson A, Custovic A. Pets and the development of allergic sensitization. Curr Allergy Asthma Rep. 2005;5:212-220.

3. Munir AK, Kjellman NI, Bjorksten B. Exposure to indoor allergens in early infancy and sensitization. J Allergy Clin Immunol. 1997;100: $177-181$.

4. Custovic A, Fletcher A, Pickering CA, et al. Domestic allergens in public places III: House dust mite, cat, dog and cockroach allergens in British hospitals. Clin Exp Allergy. 1998;28:53-59.

5. Custovic A, Simpson A, Pahdi H, Green RM, Chapman MD, WoodcockA. Distribution, aerodynamic characteristics, and removal of the major cat allergen Fel d1 in British homes. Thorax. 1998;53:33-38.

6. Tavernier G, Fletcher G, Gee I, et al. Ipeadam study: Indoor endotoxin exposure, family status, and some housing characteristics in English children. J Allergy Clin Immunol. 2006;117:656-662.

7. Heinrich J, Gehring U, Douwes J, et al. Pets and vermin are associated with high endotoxin levels in house dust. Clin Exp Allergy. 2001; 31:1839-1845.

8. Platts-Mills JA, Custis NJ, Woodfolk JA, Platts-Mills TA. Airborne endotoxin in homes with domestic animals: Implications for cat-specific tolerance. J Allergy Clin Immunol. 2005;116:384-389.

9. Lau S, Illi S, Platts-Mills TA, et al. Longitudinal study on the relationship between cat allergen and endotoxin exposure, sensitization, cat-specific IgG and development of asthma in childhood - report of the German Multicentre Allergy Study (MAS 90). Allergy. 2005;60:766-773.

10. Eller E, Roll S, Chen CM, et al. Meta-analysis of determinants for pet ownership in 12 European birth cohorts on asthma and allergies: A GA2 LEN initiative. Allergy. 2008;63:1491-1498.

11. Kerkhof M, Wijga AH, Brunekreef B, et al. Effects of pets on asthma development up to 8 years of age: The PIAMA study. Allergy. 2009; 64:1202-1208.

12. Woodcock A, Addo-Yobo EO, Taggart SC, et al. Pet allergen levels in homes in Ghana and the United Kingdom. J Allergy Clin Immunol. 2001;108:463-465.

13. Simpson BM, Custovic A, Simpson A, et al. NAC Manchester Asthma and Allergy Study (NACMAAS): Risk factors for asthma and allergic disorders in adults. Clin Exp Allergy. 2001;31:391-399.

14. Al-Mousawi MS, Lovel H, Behbehani N, Arifhodzic N, Woodcock A, Custovic A. Asthma and sensitization in a community with low indoor allergen levels and low pet-keeping frequency. JAllergy Clin Immunol. 2004;114:1389-1394.

15. Addo-Yobo EO, Custovic A, Taggart SC, Craven M, Bonnie B, Woodcock A. Risk factors for asthma in urban Ghana. J Allergy Clin Immunol. 2001;108:363-368.

16. Tunnicliffe WS, Fletcher TJ, Hammond K, et al. Sensitivity and exposure to indoor allergens in adults with differing asthma severity. Eur Respir J. 1999;13:654-659.

17. Custovic A, Green R, Taggart SC, et al. Domestic allergens in public places. II: Dog (an f1) and cockroach (Bla g2) allergens in dust and mite, cat, dog and cockroach allergens in the air in public buildings. Clin Exp Allergy. 1996;26:1246-1252.

18. Roost HP, Kunzli N, Schindler C, et al. Role of current and childhood exposure to cat and atopic sensitization. European Community Respiratory Health Survey. J Allergy Clin Immunol. 1999;104:941-947.

19. De Lucca SD, O'Meara TJ, Tovey ER. Exposure to mite and cat allergens on a range of clothing items at home and the transfer of cat allergen in the workplace. J Allergy Clin Immunol. 2000;106:874-879.

20. Lambrecht BN, Hammad H. Lung dendritic cells: Targets for therapy in allergic disease. Handb Exp Pharmacol. 2009;188:99-114.
21. Levy O. Innate immunity of the newborn: Basic mechanisms and clinical correlates. Nat Rev Immunol. 2007;7:379-390.

22. Wegmann TG, Lin H, Guilbert L, Mosmann TR. Bidirectional cytokine interactions in the maternal-fetal relationship: Is successful pregnancy a Th2 phenomenon? Immunol Today. 1993;14:353-356.

23. Orgel HA, Hamburger RN, Bazaral M, et al. Development of IgE and allergy in infancy. J Allergy Clin Immunol. 1975;56:296-307.

24. Kjellman NI, Croner S. Cord blood IgE determination for allergy prediction - a follow-up to seven years of age in 1,651 children. Ann Allergy.1984;53:167-171.

25. Magnusson CG. Cord serum IgE in relation to family history and as predictor of atopic disease in early infancy. Allergy. 1988;43:241-251.

26. Eiriksson TH, Sigurgeirsson B, Ardal B, Sigfusson A, Valdimarsson H. Cord blood IgE levels are influenced by gestational age but do not predict allergic manifestations in infants. Pediatr Allergy Immunol. 1994;5:5-10.

27. Hide DW, Arshad SH, Twiselton R, Stevens M. Cord serum IgE: An insensitive method for prediction of atopy. Clin Exp Allergy. 1991;21: 739-743.

28. Sadeghnejad A, Karmaus W, Davis S, Kurukulaaratchy RJ, Matthews S, Arshad SH. Raised cord serum immunoglobulin E increases the risk of allergic sensitisation at ages 4 and 10 and asthma at age 10. Thorax. 2004;59:936-942.

29. Platts-Mills TA, Erwin EA, Allison AB, et al. The relevance of maternal immune responses to inhalant allergens to maternal symptoms, passive transfer to the infant, and development of antibodies in the first 2 years of life. J Allergy Clin Immunol. 2003;111:123-130.

30. Aichbhaumik N, Zoratti EM, Strickler R, et al. Prenatal exposure to household pets influences fetal immunoglobulin E production. Clin Exp Allergy. 2008;38:1787-1794.

31. Kondo N, Kobayashi Y, Shinoda S, et al. Cord blood lymphocyte responses to food antigens for the prediction of allergic disorders. Arch Dis Child. 1992;67:1003-1007.

32. Smillie FI, Elderfield AJ, Patel F, et al. Lymphoproliferative responses in cord blood and at one year: No evidence for the effect of in utero exposure to dust mite allergens. Clin Exp Allergy. 2001;31:1194-1204.

33. Prescott SL, Macaubas C, Holt BJ, et al. Transplacental priming of the human immune system to environmental allergens: Universal skewing of initial $\mathrm{T}$ cell responses toward the Th2 cytokine profile. J Immunol. 1998;160:4730-4737.

34. Rowe J, Kusel M, Holt BJ, et al. Prenatal versus postnatal sensitization to environmental allergens in a high-risk birth cohort. J Allergy Clin Immunol. 2007;119:1164-1173.

35. Roponen M, Hyvarinen A, Hirvonen MR, Keski-Nisula L, Pekkanen J. Change in IFN-gamma-producing capacity in early life and exposure to environmental microbes. J Allergy Clin Immunol. 2005; 116:1048-1052.

36. Lappalainen MH, Roponen M, Hyvarinen A, et al. Exposure to environmental bacteria may have differing effects on tumour necrosis factor-alpha and interleukin-6-producing capacity in infancy. Clin Exp Allergy. 2008;38:1483-1492.

37. Lappalainen M, Roponen M, Pekkanen J, Huttunen K, Hirvonen MR. Maturation of cytokine-producing capacity from birth to $1 \mathrm{yr}$ of age. Pediatr Allergy Immunol. 2009;20:714-725.

38. Gern JE, Reardon CL, Hoffjan S, et al. Effects of dog ownership and genotype on immune development and atopy in infancy. J Allergy Clin Immunol. 2004;113:307-314.

39. Bufford JD, Reardon CL, Li Z, et al. Effects of dog ownership in early childhood on immune development and atopic diseases. Clin Exp Allergy. 2008;38:1635-1643.

40. Ly NP, Li Y, Sredl DL, et al. Elevated allergen-induced il-13 secretion predicts IgE elevation in children ages 2-5 years. J Clin Immunol. 2005;25:314-320.

41. Perzanowski MS, Chew GL, Divjan A, et al. Cat ownership is a risk factor for the development of anti-cat IgE but not current wheeze at age 5 years in an inner-city cohort. J Allergy Clin Immunol. 2008;121:1047-1052. 
42. Arshad SH, Tariq SM, Matthews S, Hakim E. Sensitization to common allergens and its association with allergic disorders at age 4 years: A whole population birth cohort study. Pediatrics. 2001; 108:E33.

43. Ownby DR, Johnson CC, Peterson EL. Exposure to dogs and cats in the first year of life and risk of allergic sensitization at 6 to 7 years of age. JAMA. 2002;288:963-972.

44. Remes ST, Castro-Rodriguez JA, Holberg CJ, Martinez FD, Wright AL. Dog exposure in infancy decreases the subsequent risk of frequent wheeze but not of atopy. J Allergy Clin Immunol. 2001;108:509-515.

45. Brussee JE, Smit HA, van Strien RT, et al. Allergen exposure in infancy and the development of sensitization, wheeze, and asthma at 4 years. J Allergy Clin Immunol. 2005;115:946-952.

46. Custovic A, Simpson BM, Simpson A, Kissen P, Woodcock A. Effect of environmental manipulation in pregnancy and early life on respiratory symptoms and atopy during first year of life: A randomised trial. Lancet. 2001;358:188-193.

47. Torrent M, Sunyer J, Munoz L, et al. Early-life domestic aeroallergen exposure and IgE sensitization at age 4 years. J Allergy Clin Immunol. 2006;118:742-748.
48. Lau S, Illi S, Sommerfeld C, et al. Early exposure to house-dust mite and cat allergens and development of childhood asthma: A cohort study. Multicentre Allergy Study Group. Lancet. 2000;356:1392-1397.

49. Platts-Mills T, Vaughan J, Squillace S, Woodfolk J, Sporik R. Sensitisation, asthma, and a modified th2 response in children exposed to cat allergen: A population-based cross-sectional study. Lancet. 2001; 357:752-756.

50. Burr ML, Merrett TG, Dunstan FD, Maguire MJ. The development of allergy in high-risk children. Clin Exp Allergy. 1997;27:1247-1253.

51. Hagendorens MM, Bridts $\mathrm{CH}$, Lauwers $\mathrm{K}$, et al. Perinatal risk factors for sensitization, atopic dermatitis and wheezing during the first year of life (PIPO study). Clin Exp Allergy. 2005;35:733-740.

52. Bisgaard H, Simpson A, Palmer CN, et al. Gene-environment interaction in the onset of eczema in infancy: Filaggrin loss-of-function mutations enhanced by neonatal cat exposure. PLoS Med. 2008;5:e131.

53. Kurukulaaratchy RJ, Waterhouse L, Matthews SM, Arshad SH. Are influences during pregnancy associated with wheezing phenotypes during the first decade of life? Acta Paediatr. 2005;94:553-558.
Journal of Asthma and Allergy

\section{Publish your work in this journal}

The Journal of Asthma and Allergy is an international, peer-reviewed open-access journal publishing original research, reports, editorials and commentaries on the following topics: Asthma; Pulmonary physiology; Asthma related clinical health; Clinical immunology and the immunological basis of disease; Pharmacological interventions and

\section{Dovepress}

new therapies. Issues of patient safety and quality of care will also be considered. The manuscript management system is completely online and includes a very quick and fair peer-review system, which is all easy to use. Visit http://www.dovepress.com/testimonials.php to read real quotes from published authors. 